DOI: https://doi.org/10.31874/2309-1606-2019-24-1-224-230

УДК: 37.03

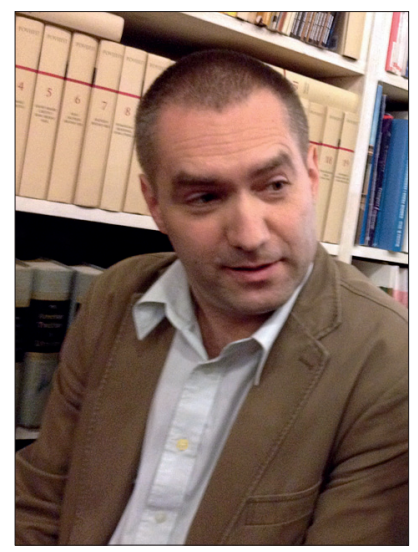

Amir MUZUR

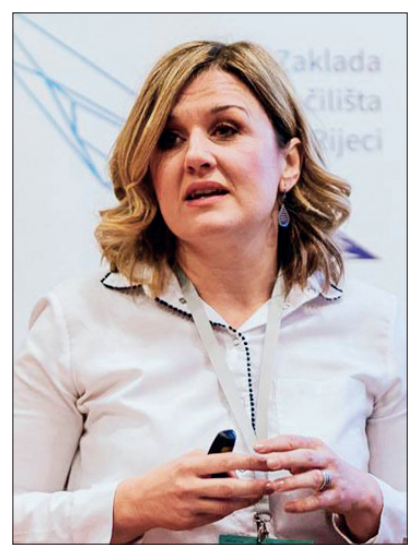

Iva RINČIĆ

\title{
PIETISM AND EDUCATION IN THE LIFE AND WORK OF FRITZ JAHR
}

\section{Annotation}

A little bit more than twenty years ago, the attention of bioethics community was attracted by the discovery of the work of Fritz Jahr (1895-1953), a theologian and teacher from Halle (Germany), who had conceived both the term and the discipline of bioethics (Bio-Ethik, 1926) by broadening Kant's categorical imperative onto animals and plants. Today, dozens of papers deal with Jahr's bioethics ideas, but his work related to other topics remains almost unknown. In the present paper, we address Jahr's article from 1930, devoted to education ("Gesinnungsdiktatur oder Gedenkfreiheit? Gedanken über eine liberale Gestaltung des Gesinnungsunterrichts" [Dictatorship of worldview or freedom of thought? Considerations on the liberal structuring of teaching of attitudes]). In the article, published in Die neue Erziehung, Jahr advocates a set of ten quite progressive and free-minded principles, including objectivity, pluriperspectivism (verschiedene Gesinnungseinstellungen), tollerant dialogue, autonomy, rationalism, liberalism, and democratization of education system and of the development of worldview at school. We devote particular attention to the comparison of Jahr's ideas to the doctrine of Pietism and August Hermann Francke, who established the Foundation in which Jahr spent a significant part of his life, first as a student, and later as a teacher.

Key words: Bio-ethics, pietism, the Pietistic principles of education

The state of society today in Croatia is difficult to define. It is a dynamic resultant of intertwining processes of different degrees of expansion and generality, which includes digitalised neurodeformation, information glo- 
balisation, Americanisation (that is, pragmatism, alienation and media manipulation), post-socialist political and economic transition, and so on and so forth. In the consequent chaos of values and value systems, insisting on formal education in the socio-humanistic field may of course look like a quixotic, futile, impossible and even pointless determination to set sail in a storm. Still, the question is whether there is anything else left to do other than try and impose - through a disrupted but single system of (bio)ethical education - information and reflection on values whose durability, in spite of everything, no one has been able to deny so far. The problem of detaching oneself from general social tendencies is all the more alarming, as a recent study reveals that in our society even students of medicine, who are traditionally considered to be the most dissociated from social trends, during their study succumb to a regression of moral reasoning (Hren, 2011: 1-9).

In the given situation, it is justifiable to reach for analyses of all educational systems, even those that have fallen into oblivion or have never been pulled out of it, such as the ideas of Fritz Jahr, a German theologian and teacher from Halle, who has gradually become known over the last twenty years as the first author of the term and concept of bioethics.

Jahr spent a significant part of his own schooling in the educational institutions of the Francke Foundation (Franckesche Stiftung), at first in the higher classes of elementary school (Mittelschule), and then from 1905 in secondary school (Realgymnasium) (Francke Foundation Archive in Halle). Jahr later returned to these schools twice to work as a teacher. The foundation founded by August Hermann Francke (1663-1727) based its charitable work and teaching on Pietism - a variant of Lutheran Protestantism that was conceived and brought to Halle by Francke and his role model Philipp Jakob Spener.

\section{Jahr on education}

Although dozens of articles have already been published that at least make mention of Jahr's work in bioethics, some of which dissect Jahr's bioethical imperative more closely, little attention has been paid so far to Jahr's work in other areas. The purpose of this chapter is to help rectify this omission by presenting and discussing Jahr's article on education, entitled 'Gesinnungsdiktatur oder Gedenkfreiheit? Gedanken über eine liberale Gestaltung des Gesinnungsunterrichts' ['The dictatorship of convictions (Sass, 2010: 16-17) (1) or freedom of thought? Thoughts about a liberal formation of an education on convictions'] (Jahr, 1930: 200-202).

The article was published in 1930 (when Jahr was 35 and still not married, but already with health problems that would result in his retirement three years later) in the Die neue Erziehung: Monatschrift für entschiedene Schulreform und freiheitliche Schulpolitik [New Education: The Monthly Journal for Resolute School Reform and Liberal School Policy] magazine, which was published from 1919 to 1933 in Jena. 
Starting from the assumption that convictions are based on moral judgments, Jahr does not deny the importance of science in their formation, although he notes that even 'objective' scientific facts are often used to draw subjective, individual interpretations and conclusions. In his criticism of the prevailing practice of his time, Jahr accuses religious education of neglecting the arguments of other religions. With regard to the teaching of German and history, he condemns the insistence on patriotism and loyalty, which, although desirable, deny any freedom and impose a dictatorship of certain convictions. To eliminate conditioning and stimulate liberalism, that is, the 'democratisation' of convictions (Liberalismus bzw. 'Demokratisierung' der Gesinnung), Jahr proposes ten principles (2):

1. Do not teach predetermined, subjective convictions;

2. Strictly avoid disguising predetermined convictions with alleged objectivity and false 'advanced teaching methods' (3);

3. It is methodologically unacceptable to take into consideration only what fits, and to suppress, deny or manipulate 'inconvenient' facts;

4. Always consider different convictions Gesinnungseinstellungen);

5. One should also discuss different, mutually opposing convictions, their benefits and shortcomings on an equal basis and impartially (instead of seeing one's own through rose-tinted glasses and others' through dark ones);

6. When presenting personal opinions, it must be done in an impartial manner and with due attention to the problematic nature of one's own convictions;

7. Instead ofhavingbiased convictionsimposed onthem(Gesinnungsmacherei), students should be given the opportunity to form their own ones or be given objective material so they can form their own convictions at a later date;

8. The saying that 'reason and science are people's biggest strength' should never be forgotten when forming new or reviewing existing convictions. It is therefore wrong to accept the principle proposed by a newspaper from Munich: 'Convictions first, reason second!' In any case, it would even be satisfactory if 'reason' were only used to subsequently review convictions in an objective manner;

9. One should not claim that young people are only suited for the method of authority instead of the method of freedom, which is a claim that should not remain uncontested. But even if it is so, seeding always precedes harvesting! The practical implications for religious education stem from the 'Guidelines for High School Curricula in Prussia', where methodological remarks on certain areas of teaching explicitly state that religious education in classrooms must merely provide suitable material about which students can later reach their own decisions independently; 
10.Even if the desired convictions do not develop, one should not forget that this can happen even more often under the old educational methods and teaching. Besides, independently formed convictions are better than those that have been taken on and which are childish and immature (Jahr, 1930: 201).

\section{The Pietistic principles of education}

Jahr's involvement in education was not only motivated by his own career and experiences. As with animal rights and certain other issues, Jahr once again turned towards typical Pietistic questions. While the educational principles advocated by Jahr are interesting as an anticipation, for example, of the pluri-perspectivism of the integrative bioethics of Ante Čović (Gesinnungseinstellungen), they are nevertheless significantly different from Pietistic ones.

The ideologist of Pietism and the author of the foundations with which Jahr was closely connected, August Hermann Francke, claimed that the improvement of society must start with teachers (Menck, 2001: 20). According to him, the means of education are primarily examples (Exempel), and warnings/threats and punishments (Verheißungen und Strafen) (Menck, 2001: 44). Teaching is dominated by the methodus erotematica, according to which lessons, after a short lecture, are reinforced through questions and answers (catechism). First, there is the recitatio - the reading of the text, then the explicatio - the explanation, questions and answers, and finally the applicatio - appropriateness in terms of true piety) (Hein, 1996: 57). Francke believed that the results of a correct upbringing must already be visible at the age of eight or nine, which involved following God's will rather than one's own, which must be broken at any cost ([...] wohl daran gelegen, daß der natürliche EigenWille gebrochen werde) (Menck, 2001: 28). Moreover, Francke stands against science in favour of religion (Ach ja, ihr Lieben, ein Tröpfchen Glaubens ist weit herrlicher, als ein ganzes Meer voller Wissenschaften, und wäre es auch selbst die historische Wissenschaft des göttlichen Worts [Theologie]) (Menck, 2001: 32). Francke published the principles of such an education in 1693 in the book Glauchische Gedenk-Büchlein (intended for his students in Glaucha) and in his most important educational treatise, published in 1702 and entitled Kurzer und einfältigter Unterricht wie die Kinder zur wahren Gottseligkeit und christlichen Klugheit anzuführen sind (Widén, 1967: 7).

As Juliane Dittrich-Jacobi has pointed out, the typical features of the Francke Foundation schools (the Pädagogium, the lateinische Ausleseschule, and the Armenstudium in the orphanage or Waisenhaus located in the area of Halle known as Glaucha) were the institutionalisation and ritualisation of the teacher-student relationship, the suppression and disciplining of immediacy and independence, the ritualisation of punishment, and, in spite of everything, the development of a close relationship between teachers and 
students in accordance with the principle of upbringing in piety (DittrichJacobi, 1976: 273).

\section{Jahr vs. Francke or a conclusion}

A comparison of the educational principles promoted by Fritz Jahr and those imposed by August Hermann Francke as a doctrine reveals they are in direct opposition. We can imagine what kind of pressure Jahr must have been exposed to while learning and working in an institution that imposed principles contrary to his own. One cannot rule out the possibility that the instability of Fritz Jahr's career and his 'nervous exhaustion' were at least partly provoked by the conflict between his own liberal attitudes and the Pietistic ones which were well-established as part of the Prussian state religion and its practice. We could go even further and ask ourselves whether these strongly frustrating moments may have influenced Jahr's abandonment of Kant's anthropocentric ethics and led to the conception of a new one in the form of bioethics? However, this would be rather hard to prove.

\section{References}

Dittrich-Jacobi J. (1976) Pietismus und Pädagogik im Konstituzionsprozess der bürgerlichen Gesellschaft: historisch-systematische Untersuchung der Pädagogik August Hermann Franckes (1663-1727). Doctoral thesis, University of Bielefeld Faculty of Pedagogy, Philosophy and Psychology, 273.

Hren D., Marušić M. (2011) Regression of moral reasoning during medical education: combined design study to evaluate the effect of clinical study years, PlosOne, 6 (3), 1-9.

Hein U. (1996) Der Pietismus und seine Bedeutung für die Pädagogik unter besonderer Berücksichtigung August Hermann Franckes. Master's thesis, Faculty of Philosophy of the 'Christian Albrecht' University in Kiel, 57.

Francke Foundation Archive in Halle. Schüleralbum von Ostern 1885 bis Ostern 1914: Realgymnasium der Franckeschen Stiftungen zu Halle a.d. Saale. III IS B I 7.

Menck P. (2001) Die Erziehung der Jugend zur Ehre Gottes und zum Nutzen des Nächsten: die Pädagogik August Hermann Franckes. Tübingen: Verlag der Franckeschen Stuftungen im Max-Niemeyer-Verlag, 20-32.

Jahr Fr. (1930) Gesinnungsdiktatur oder Gedankenfreiheit? Gedanken über eine liberale Gestaltung des Gesinnungsunterrichts, Die neue Erziehung, 12, 200-202.

Widén B. (1967) Bekehrung und Erziehung bei August Hermann Francke, Acta Academiae Aboensis, ser. A - Humaniora, 33(3), 7.

\section{Notes}

1. In his English translation of the German word Gesinnung, Hans-Martin Sass uses several terms: character, conviction, disposition, opinion, attitude. Cf. Fritz Jahr, Selected Essays in Bioethics 1927-1934, Medizinethische Materialien, Heft 186, afterword and references by Hans-Martin Sass (Bochum: Zentrum für Medizinische Ethik, 2010), 16-17.

2. See the analysis of these principles of Jahr's in: Nada Gosić, 'The actuality of thoughts of Fritz Jahr in bioethics education or why Fritz Jahr advocates character education', Jahr 2, no. 4 (2011): 407-414; also in Fritz Jahr and the Foundations of Global 
Bioethics: The Future of Integrative Bioethics, edited by Amir Muzur and Hans-Martin Sass (Münster: Lit, 2012): 319-326; Nikolaus Knoepffler, 'Gedanken über eine liberale Gestaltung des Gesinnungsunterrichts', paper presented at the 1927 - Die Geburt der Bioethik in Halle (Saale) durch den protestantischen Theologen Fritz Jahr (18951953) conference held in Halle on 28 and 29 November 2012, and later published as: Nikolaus Knoepffler and Johannes Achatz, 'Vom Gesinnungsunterricht zur Gentechnik: zur Relevanz der gedanken Fritz Jahrs für heutige bioethische Debatten', in 1926 - Die Geburt der Bioethik in Halle (Saale) durch den protestantischen Theologen Fritz Jahr (1895-1953), eds. Florian Steger, Jan C. Joerden and Maximilian Schochow (Frankfurt a/M: Peter Lang, 2014), 113-123.

3. Arbeitsunterricht in Sass's English version is translated as interactive teaching. Cf. Fritz Jahr, Selected Essays in Bioethics 1927-1934, 17.

\section{Амір Музур, Іва Рінчич. Пієтизм і освіта у житті та роботі Фріца Яра}

Понад двадцять років тому увагу біоетичної спільноти привернуло відкриття роботи Фріца Яра (1895-1953), теолога та вчителя з Галле (Hiмеччина). Він уперше осмислив поняття біо-етика (Bio-Ethik, 1926) як новий термін і дисципліну, розширивши застосування поняття категоричного імперативу Канта до тварин і рослин. Сьогодні десятки статей присвячені ідеям біоетики Яра, але його робота, пов'язана з іншими темами, залишається невідомою. У цій статті ми розглядаємо публікацію Яpa «Gesinnungsdiktatur oder Gedenkfreiheit? Gedanken über eine liberale Gestaltung des Gesinnungsunterrichts» / «Диктатура світогляду або свобода думки? Роздуми про ліберальний дизайн морального виховання», яка опублікована в «Die neue Erziehung», 1930 році. Яр обгрунтовує комплекс 3 десяти досить прогресивних і неупереджених принципів, включаючи об'єктивність, плюріперспективізм (verschiedene Gesinnungseinstellungen), толерантний діалог, автономію, раціоналізм, лібералізм і демократизацію в системі освіти й розвитку світогляду в школі. У статті ми приділяємо особливу увагу порівнянню ідей Фр. Яра з доктриною пієтизму і ідеями Августа Германа Франке, який заснував Фонд, у якому Яр провів значну частину свого життя як студент, а згодом як учитель.

Ключові слова: біо-етика, пієтизм, пієтистичні принципи виховання.

\section{Амир Музур, Ива Ринчич. Пиетизм и образование в жизни и работе Фрица Яра}

Более двадцати лет назад внимание сообщества биоэтики привлекло открытие работ Фрица Яра (1895-1953), теолога и учителя из Галле (Германия). Он впервые осмыслил понятие Био-этика (Bio-Ethik, 1926) как термин и дисциплину, расширив применение категорического императива Канта к животным и растениям. Сегодня десятки статей посвящены идеям биоэтики Яра, но его работа, связанная с другими темами, остается неизвестной. В настоящей статье мы рассматриваем такую работу Яра 1930 года, посвященную образованию («Gesinnungsdiktatur oder Gedenkfreiheit? Gedanken über eine liberale Gestaltung des Gesinnungsunterrichts» / «Дикта- 
тура мировоззрения или свобода мысли? Размышления о либеральном дизайне нравственного воспитания»). В статье, опубликованной в «Die neue Erziehung», Яр обосновывает комплекс из десяти довольно прогрессивных и непредвзятых принципов, включая объективность, плюриперспективизм (verschiedene Gesinnungseinstellungen), толерантный диалог, автономию, рационализм, либерализм и демократизацию в системе образования и развитии мировоззрения в школе. В нашей статье мы уделяем особое внимание сравнению идей Яра с доктриной пиетизма и идеями Августа Германа Франке, который основал Фонд, в котором Яр провел значительную часть своей жизни сначала как студент, а затем как учитель.

Ключевые слова: био-этика, пиетизм, пиетистические принципы воспитания.

Amir Muzur, MD, MA, PhD, Full Professor and Head, Department of Social Sciences and Medical Humanities, Faculty of Medicine - University of Rijeka, B. Branchetta 20, 51000 Rijeka, Croatia, e-mail: amir.muzur@medri.uniri.hr

Амір Музур MD, MA, PhD, професор і завідувач кафедри соціально-гуманітарних та медичних наук, Медичний факультет Університету Рієка, B. Branchetta 20, 51000 Rijeka, Croatia; e-mail: amir.muzur@medri.uniri.hr

Iva Rincic, $\mathrm{BA}, \mathrm{MA}, \mathrm{PhD}$

Associate Professor Department of Social Sciences and Medical Humanities/ Department of Public Health; Faculty of Medicine/Faculty of Health Studies University of Rijeka.

Іва Рінчич, BA, MA, PhD

Доцентка кафедри соціально-гуманітарних та медичних наук / кафедра громадського здоров'я; Медичний факультет / Факультет медико-санітарних досліджень Університету Рієка. 